\title{
Intention to Use Accounting Platforms in Romania: A Quantitative Study on Sustainability and Social Influence
}

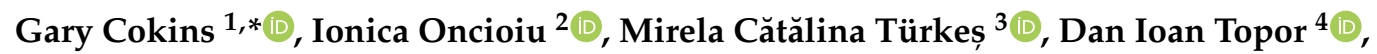

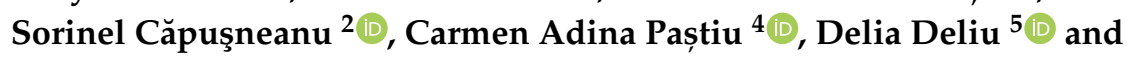 \\ Alina Nicoleta Solovăstru ${ }^{6}$ \\ 1 CPIM, Analytics-Based Performance Management LLC, Cary, NC 27513, USA \\ 2 Faculty of Finance-Banking, Accounting and Business Administration, Titu Maiorescu University, \\ 040441 Bucharest, Romania; ionicaoncioiu@yahoo.ro (I.O.); sorinelcapusneanu@ucdc.ro (S.C.) \\ 3 Faculty of Finance, Banking and Accountancy, Dimitrie Cantemir Christian University, \\ 040042 Bucharest, Romania; mirela.turkes@ucdc.ro \\ 4 Faculty of Economic Sciences, 1 Decembrie 1918 University, 510009 Alba-Iulia, Romania; \\ dan.topor@uab.ro (D.I.T.); carmenpastiu@yahoo.com (C.A.P.) \\ 5 Faculty of Economics and Business Administration, West University of Timisoara, \\ 300223 Timisoara, Romania; delia.deliu@e-uvt.ro \\ 6 Faculty of Economic Sciences, Dimitrie Cantemir University, 540099 Târgu-Mureș, Romania; \\ alina.solovastru@yahoo.com \\ * Correspondence: garyfarms@aol.com
}

Received: 4 July 2020; Accepted: 28 July 2020; Published: 30 July 2020

\begin{abstract}
Technological innovation evolves through the use of information systems and this study highlights the intentions of using accounting platforms by conducting a quantitative study on sustainability and its social influence. The purpose of this study is to investigate the factors that influence the acceptance and use by company managers of accounting platforms available online by developing the unified theory of acceptance and use of technology (UTAUT) construct model. The research method used in the quantitative study was the sample survey, using the online questionnaire as a data collection tool. A number of 401 companies provided complete and useful answers to this research. The major contributions of the research were the use of two variables considered significant in the study: perceived credibility (PC) and perception of risk (PR). The results of the study showed that performance expectancy (PE), social influence (SI), and perceived risk (PR) have a positive influence on the intention to use the accounting platforms available online, while perceived credibility shows a much more significant and stronger influence.
\end{abstract}

Keywords: social influence; accounting platform; UTAUT model; usage intention; perceived credibility; perceived risk

\section{Introduction}

The decision-making process by users of financial information has been radically improved due to technological innovations through the use of computer systems that produce reliable, relevant, timely, and testable financial information. 2020 is the year of online platforms for company managers. With the transition from processing transaction data on paper to electronic media, online accounting platforms, and various computer programs have emerged, including large databases, and help process companies' transactions. These online platforms fulfill multiple functions such as: supporting and facilitating the activity, generating and quick access to documents, easily facilitating the connection with investors interested in innovation from foreign countries, etc. 
The competence of the users of accounting information is reflected through the process of adoption and transfer of technology that is achieved through the successful implementation of information technology. This success depends to a large extent on the users' desire to adopt, transform, and acquire new technological skills. The interaction between users and technological information systems can create certain behavioral problems as a result of refusal to adopt or inability to meet new technological challenges. The behavioral aspects of users that affect the successful acceptance of information systems technology are influenced by factors such as: attitude, perception [1,2], and characteristic differences [3].

User acceptance of new information systems or accounting platforms can be achieved by changing behavior and training before using them [4]. One of the theories that explains the acceptance of technology is the technology acceptance model or Technology Acceptance model (TAM) developed by [5] and based on the Theory of Reasoned Action (TRA) being used to measure the level of acceptance of technology users. This model started from the definition of the two factors that affect the acceptance of technology by users, namely the perceived usefulness and the perceived ease of use of the technology.

The purpose of this study is to investigate the factors that influence the acceptance and use by business managers of accounting platforms available online. Consequently, the six research questions of the study aim at: (1) the performances expected by the companies' management following the use of the online platform; (2) developing learning, communication, and platform browsing experiences; (3) assessing people's behavior (employees, customers, suppliers, etc.) and measuring their involvement in programs aimed at solving social problems; (4) issues related to the security and privacy of online platforms; (5) the availability and knowledge required to use the platform plus the technical support required for the operation; (6) the main risks generated by the organization and management of accounting on online platforms.

The novelty elements of this research covered the aspects related to the use of the unified theory of acceptance and use of technology (UTAUT) construct model in investigating the factors that influence the acceptance and utilize by company managers of accounting platforms available online. The results add new evidence to that on the company's need to trust the accounting platforms, and then accept changes in a system that is really sustainable for society in a digital world. However, the present study highlights the necessity of an open discussion on the consequences of digitalization in accounting. Finally, our findings are relevant in order to identify the risks regarding the intention to use an accounting platform.

The content of the article is structured in accordance with the proposed purpose and objectives, with a brief presentation of the literature in Section 2, a presentation of the research methodology and data source in Section 3, and the empirical results are presented and discussed in Section 4. Finally, the conclusions and limitations of the study are presented in Section 5.

\section{Literature Review and Hypothesis Development}

\subsection{Theoretical Analysis of Unified Theory of Acceptance and Use of Technology (UTAUT)}

Over time, various theoretical models have been designed to predict the adoption and use of technology. The key to implementing any type of technology is based on the study of human behavior as part of the information system. The unified theory acceptance and use of technology (UTAUT) is a framework designed by [6] to predict the acceptance of technology in organizational implementations, being known as TAM 2. UTAUT is based on the integration of the dominant constructs of eight predominant prior models that vary from human behavior to computer science. From a chronological point of view, the eight models are presented as follows: (1) the Theory of Motivated Action [7]; (2) the Technology of Acceptance Model or TAM 1 [5]; (3) the Model of PC Use (MPCU) [8]; (4) the Theory of Planned Behavior [9]; (5) the Motivational Model [10]; (6) TAM and theory of planned behavior (TPB) combined [11]; (7), Social Cognitive Theory [12]; and (8) Innovation Diffusion Theory [13]. 
Developed by reviewing and consolidating the eight models presented above, UTAUT is a very comprehensive theory [6] that is based on four key exogenous or independent variables that affect the behavioral intention to use technology, namely: (1) hope performance; (2) effort expectation; (3) behavioral social influence; and (4) facilitation conditions that have a direct impact on technology use [14]. Previous studies conducted by specialists have indicated that the relationship between independent and dependent factors is most often moderated by different variables such as: age, experience, and volunteering [15].

The results revealed that UTAUT constructions are affected by many external variables throughout the various studies undertaken in several European and Asian countries [16-22]. In the process of selecting different theories and integrating them into the construction of different models, specialists continue to investigate. The most common research and investigation methods were cross-sectional studies based on: surveys, questionnaires, and interviews. Frequent analysis techniques were: regression, partial least squares, modeling of structural equations, and confirmation factor analysis.

\subsection{Bibliometric Analysis of UTAUT Constructs}

\subsubsection{Performance Expectancy (PE)}

Performance expectations refer to a person's level of confidence that can help improve performance through the use of information systems. In the UTAUT model, performance expectancy was obtained from perceived utility (TAM/TAM2), relative advantage (TDI), job fit (MPCU), extrinsic reasons (MM), and outcome expectations (SCT) [6]. Perceived utility has a strong and consistent relationship with information technology [5].

This variable is considered as a significant predictor for the behavioral intention of consumers, especially if the technology offers them benefits in performing certain activities. A strong positive relationship has been identified between work adequacy and the use of information systems [23]. Specialist studies have shown that users' expectations for technology adoption will be high, and perceived utility will also have a significant impact on user satisfaction [24-26] and the intention to use information systems [27]. Therefore, we consider that the performance expectation will have a positive impact on the intention to use the accounting platform and the first hypothesis that will be tested will be:

Hypothesis 1 (H1). The performance expectation has an impact on the intention to use the accounting platform.

\subsubsection{Effort Expectancy (EE)}

Effort expectancy refers to the degree of ease in the use of technology by consumers, being a component previously developed from the perceived ease of TAM, ease of use (IDT), and complexity of technology (MPCU). User convenience has a positive influence on the use of information technology [5]. Benefiting from the technology that is in the possession of users and the ease of use, it creates a feeling of comfort for users. The level at which innovation is perceived as relatively difficult for individuals to interpret and use is given by its complexity [28]. Specialist studies have shown a reluctance to use information technology or systems by users, in the sense that users making efforts to use the information system will become effective and the level of user satisfaction will increase [26]. Companies' expectations have a positive influence on the intention to use information systems [23,27]. We therefore believe that the effort expectancy will have a significant impact on the intention to use the accounting platform. The second hypothesis tested will be:

Hypothesis 2 (H2). Effort expectancy has an impact on the intention to use the accounting platform. 


\subsubsection{Social Influence (SI)}

Social influence refers to the extent to which consumers believe that their friends or families should influence the use of a certain technology or the importance given by certain individuals to the use of an information system within a company. This variable was developed as part of the evolution of the subjective norms of TRA, TAM2, theory of planned behavior/decomposed theory of planned behavior (TPB/DTPB) and social factors in MPCU, and ease of use (IDT). Social influences are represented by related constructions such as: subjective norms, social factors, and images [6]. Despite the different terms, each of these constructions contains an explicit or implicit notion that an individual's behavior is influenced by how he believes that others will view them based on the results obtained after using the system. A strong positive relationship has been identified between the social influence that associates the norms and behavior of society [29] and the intention to use information systems [23,27]. In other words, users are also influenced by other factors in their circle [30] following their instructions much more effectively. We therefore believe that social influence will have a significant impact on the intention to use the accounting platform. The third hypothesis tested will be:

Hypothesis 3 (H3). Social influence has an impact on the intention to use the accounting platform.

\subsubsection{Facilitating Conditions (FC)}

Facilitating conditions refers to consumers' perceptions of the resources and assistance available to perform a behavior or those "objective factors" that may facilitate action [31]. This variable is constructed from the control of perceived behavior (TPB/DTPB, C-TAM-TPB), MPCU, and IDT compatibility. A person's confidence in using the accounting platform will increase if it is supported by the company's organizational and technical infrastructure. It is said that the relationship between the conditions that facilitate the use of accounting platforms is positive if the level of factors that can facilitate the use of accounting platforms is high, so that the behavior of using accounting platforms will be high. This refers to the theory of reasoned action (TRA) which states that a person will use information technology on the grounds that the technology or system will benefit himself. A strong positive relationship has been identified between conditions that facilitate the use of information systems and user intentions [6,23]. If users do not intend to accumulate the knowledge needed to cope with the technology and use it properly, then this translates into a loss of being deprived of the benefits of technology [29]. Expert studies suggest that it is more important for users to be provided with knowledge and information about accounting platforms or information systems, thus coping with their use and indicating that the technology is obvious. We therefore consider that the facilitation of the conditions significantly affects the intention to use an accounting platform. The fourth hypothesis tested will be:

Hypothesis 4 (H4). Facilitating conditions affects the intention to use the accounting platform.

Starting from the initial UTAUT model, the specialists tried to develop it by creating what is called UTAUT 2 by using other variables in addition to the four variables presented above. Thus, the specialists also used: delivery efficiency, cost-saving efficiency, online shopping experience in online commerce [32], quality of systems and quality of services in making payments through mobile telephony services by integrating UTAUT, the information systems success model (D\&M ISS), and the task-technology fit model (TTF) [33]; hedonic motivation, familiarity with the concept of carsharing and emerging electric carsharing in the case of passengers on electric means of transport in China [34]; information quality, habitat (habit) in the case of food delivery through e-commerce computer applications [35]; hedonic motivation, the orientation to save prices, the habit of searching and booking restaurants using computer applications [36]; physical support and educational support for water purification systems [37]; habituation and demography in the case of integrating sustainability 
values (SV), theory of planned behavior (TPB), and UTAUT2 in the case of studying the options of travelers interested in sustainable hosting business [38].

In addition to the variables presented, we used in our study variables such as: perception of consequences (PCs) and perceived credibility (PC) that we consider to have a significant impact on the intention to use mobile accounting platforms.

\subsubsection{Perceived Consequences (PCs)}

A person's behavior is an expression of his desire or intention, in which the desire is influenced by social factors, feelings (affectation) and consequences that are felt or perceived [31]. The behavior of using information technologies is given by the intensity and frequency of users who use information technology. The Theory of Planned Behavior (TPB) states that the greater the perceived behavioral control, the stronger one's intention to perform the behavior under consideration. There is a strong positive relationship between the conditions for facilitating or perceiving the consequences and the intention to use information systems [6].

\subsubsection{Perceived Credibility (PC)}

Perceived credibility is a variable that does not come from the UTAUT model but that previous researchers have used in their studies to identify the behavioral intention to use risk-free mobile banking services $[15,39]$. We therefore believe that the perceived credibility will have a positive impact on the intention to use an accounting platform. The fifth hypothesis tested will be:

Hypothesis 5 (H5). Perceived credibility has an impact on the intention to use the accounting platform.

\subsubsection{Perceived Risk (PR)}

Perceived risk refers to the risk that users believe they may have when certain accounting platforms do not guarantee the security of their data or transactions. In other words, perceived risk negatively influences attitudes $[40,41]$ and the intention to use information technology [42] or remote payment systems $[43,44]$. In our research, risks were considered essential because they are considered a precedent for users' intention to use information technologies. Therefore, we propose this sixth research hypothesis:

Hypothesis 6 (H6). Perceived risk has an impact on the intention to use the accounting platform.

The research model based on the hypothesis development mentioned above is shown as Figure 1. 


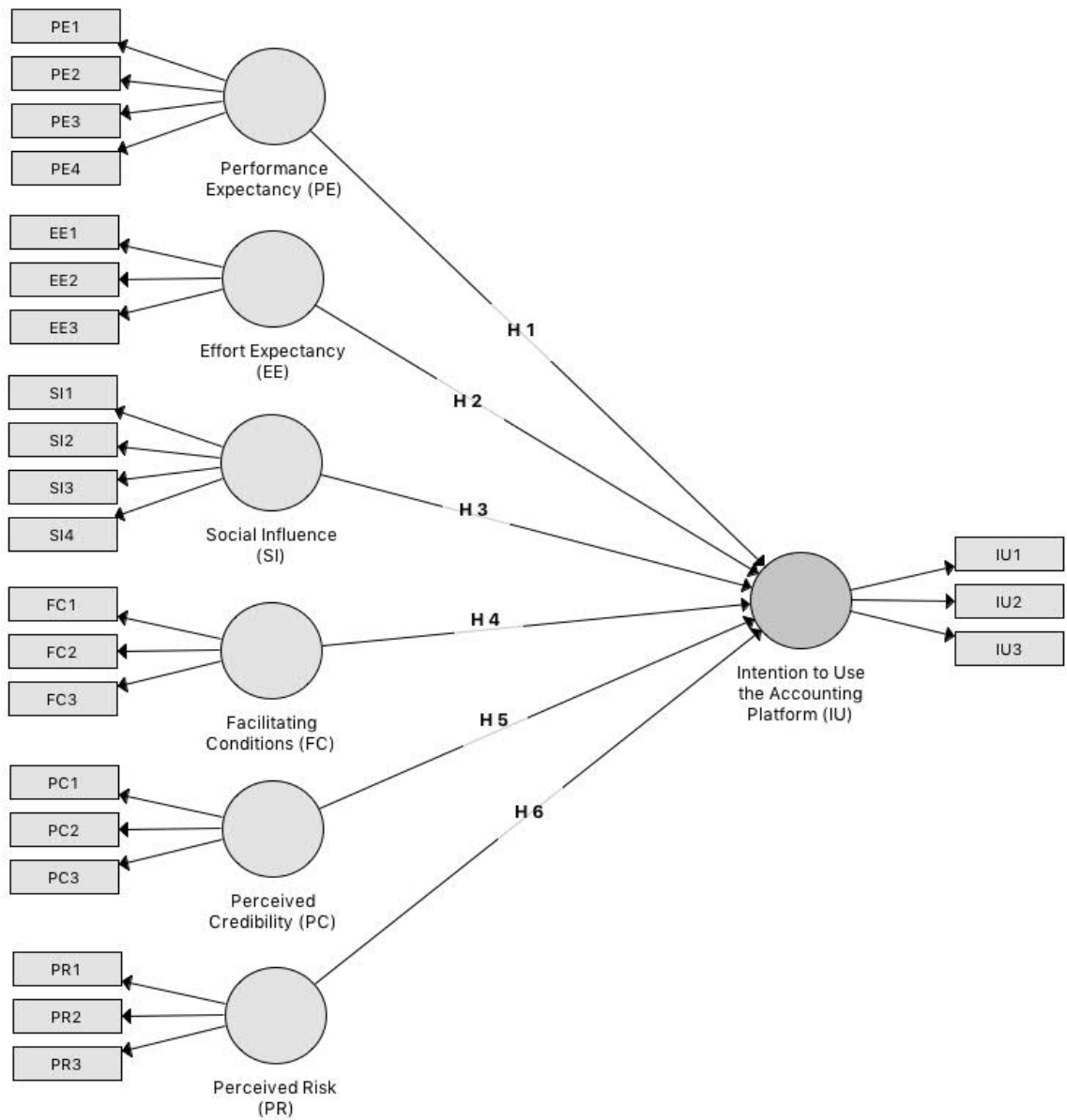

Figure 1. Research model.

\section{Methodology of Research}

\subsection{Collecting Data}

The quantitative marketing research took place between 20 November 2019 and 25 February 2020 and was based on a survey conducted among companies in Bucharest-Romania, in order to meet the research objectives and validate the six hypotheses that were formulated.

The data and information needed for the research were collected using an online questionnaire sent to companies in the form of a link via e-mail. The method is efficient by offering many advantages such as: medium to high flexibility in data collection, high degree of convenience for the respondent and low costs of data collection [45]. The researched population targeted Romanian companies in Bucharest, different in size, form of organization and industry, being identified in the databases of ISSN and the Chamber of Commerce and Industry of Romania. The sampling base was established by extracting a random sample from the reference population and drawing up a cross-list of 1200 companies. The questionnaire was distributed in the form of a link by e-mail to the companies in the cross-list, interested in using mobile accounting platforms. The questionnaire included 36 questions (32 content questions and 4 identification questions) and was structured in three stages: (stage 1) demographic information, (stage 2) exogenous variables, and (stage 3 ) endogenous variables. A total of 401 companies answered the questions in full, although 1200 questionnaires were sent by e-mail to the managers of the cross-list companies. In Table A1 (Appendix A), it can be seen that $63.6 \%$ of respondents were companies with no more than 100 employees. Almost half of the sample consisted of limited liability companies (34.2\%) and joint stock companies (12\%). According to the survey report, only $16 \%$ of companies currently use mobile accounting platforms. 
The questionnaire includes 32 questions with specific content for the 7 constructs of the model (Table 1): performance expectancy (PE), effort expectancy (EE), social influence (SI), perceived credibility (PC), facilitating conditions (FC), perceived risk (PR), and intention to use the accounting platform (IU).

Table 1. Model construct and exogenous variables.

\begin{tabular}{|c|c|c|}
\hline Model Construct & Exogenous Variables & Sources \\
\hline \multirow{5}{*}{ Performance Expectancy (PE) } & In carrying out the company's activity & \\
\hline & $\begin{array}{l}\text { (PE1) using the accounting platform would give me a real-time record } \\
\text { and good control over the business }\end{array}$ & {$[6,24]$} \\
\hline & $\begin{array}{l}\text { (PE2) Using the accounting platform would allow me to bill online and } \\
\text { use the latest technology }\end{array}$ & [23] \\
\hline & $\begin{array}{l}\text { (PE3) Using the accounting platform would give me accounting } \\
\text { consulting and representation in case of control }\end{array}$ & {$[25,26]$} \\
\hline & (PE4) Using the accounting platform would save me time & [27] \\
\hline \multirow{3}{*}{ Effort Expectancy (EE) } & $\begin{array}{l}\text { (EE1) Using the accounting platform would allow me to improve and } \\
\text { expand the learning experience }\end{array}$ & {$[23,27]$} \\
\hline & $\begin{array}{l}\text { (EE2) Using the accounting platform would allow me to develop online } \\
\text { communication skills }\end{array}$ & [26] \\
\hline & $\begin{array}{l}\text { (EE3) Using the accounting platform would allow me an easy } \\
\text { interaction with the visual interface and an easy navigation }\end{array}$ & {$[23,27]$} \\
\hline \multirow{4}{*}{ Social Influence (SI) } & $\begin{array}{l}\text { (SI1) Employees, consumers, and suppliers are very important to my } \\
\text { business so I think I should use the accounting platform }\end{array}$ & [30] \\
\hline & $\begin{array}{l}\text { (SI2) The achievements and traditions of the community are respected } \\
\text { and promoted by my business so I think I should use the } \\
\text { accounting platform }\end{array}$ & [29] \\
\hline & $\begin{array}{l}\text { (SI3) Knowing consumer behaviors provides the company with } \\
\text { guidelines for action and understanding the value of human nature so I } \\
\text { think I should use the accounting platform. }\end{array}$ & {$[6,23,27]$} \\
\hline & $\begin{array}{l}\text { (SI4) Strategic involvement in community partnerships to solve social } \\
\text { problems ensures the growth of the company's reputation so I think I } \\
\text { should use the accounting platform }\end{array}$ & {$[29,30]$} \\
\hline \multirow{4}{*}{ Facilitating conditions (FC) } & When I use the accounting platform I believe that: & \\
\hline & (FC1) I have all the necessary resources to use the accounting platform & [23] \\
\hline & (FC2) I have the necessary knowledge to use the accounting platform & [6] \\
\hline & $\begin{array}{l}\text { (FC3) I benefit from technical support for quickly solving the problems } \\
\text { caused by the use of the accounting platform }\end{array}$ & [29] \\
\hline \multirow{3}{*}{ Perceived credibility (PC) } & $\begin{array}{l}\text { (PC1) The protection of my business data is ensured with the help of } \\
\text { antivirus/antimalware software systems }\end{array}$ & [15] \\
\hline & (PC2) My business is secured by storing information on multiple servers & [15] \\
\hline & $\begin{array}{l}\text { (PC3) The confidentiality of personal data is ensured, including the user } \\
\text { and the access password to the accounting platform }\end{array}$ & [15] \\
\hline \multirow{3}{*}{ Perceived risk (PR) } & $\begin{array}{l}\text { (PR1) There is a risk of other third parties having quick access to the } \\
\text { information, documents, and financial resources of my business when } \\
\text { using the accounting platform }\end{array}$ & {$[41,42]$} \\
\hline & $\begin{array}{l}\text { (PR2) There is a significant risk of information about my business being } \\
\text { disclosed to third parties for marketing purposes through the } \\
\text { accounting platform }\end{array}$ & [43] \\
\hline & $\begin{array}{l}\text { (PR3) I consider that the organization and management of the } \\
\text { accounting records using this platform is a risky choice }\end{array}$ & [44] \\
\hline \multirow{3}{*}{$\begin{array}{l}\text { Intention to use the accounting } \\
\text { platform(IU) }\end{array}$} & (ITU1) prefer to use platform accounting services & [6] \\
\hline & (ITU2) intend to use platform accounting services & [6] \\
\hline & (ITU3) I would use platform accounting services & {$[29,30]$} \\
\hline
\end{tabular}




\subsection{Data Analysis}

Data obtained from respondents were processed using SPSS Statistics and SmartPLS3 Professional programs. The data analysis was based on the multivariate method-the partial least squares (PLS). The structural equation modeling technique was chosen to allow building a flexible model that includes several variables [46], successfully validating a proposed construct model [47], obtaining good results when using small samples [48], and high efficiency compared to other regression techniques [49]. Partial least squares (PLS) allows the analysis of the dependence of an endogenous variable on several exogenous influence variables, strongly highlighting the collinearity and correlation between them and allowing the simultaneous modeling of several response variables [50]. A 5-level ordinal scale (Likert's scale) was used to measure the variables of the proposed model [51].

\section{Results and Discussions}

Path coefficients for the proposed inner model are positive. In our study, the paths from effort expectancy (0.002), facilitating conditions (0.017), social influence (0.046), and perceived risk (0.062) to intention to use the accounting platform have positive coefficients but closer to 0 . A different situation is found in the rest of the latent variables. Although the path coefficients are standardized, the positive, closer to 1 weights obtained by perceived credibility (0.444) and performance expectancy $(0.250)$ in relation to intention to use reflect stronger positive effects, 3-4 times higher than the first four latent variables.

In Figure 2, it will be seen that the standardized path coefficients previously presented are placed on the corresponding paths to the proposed model. In the intention to use (IU) ellipse, which is also the only endogenous latent variable of the model, the R-square value is 0.476 . Therefore, approximately $47.6 \%$ of the intention for use variation is jointly explained by the six exogenous variables presented in the proposed model.

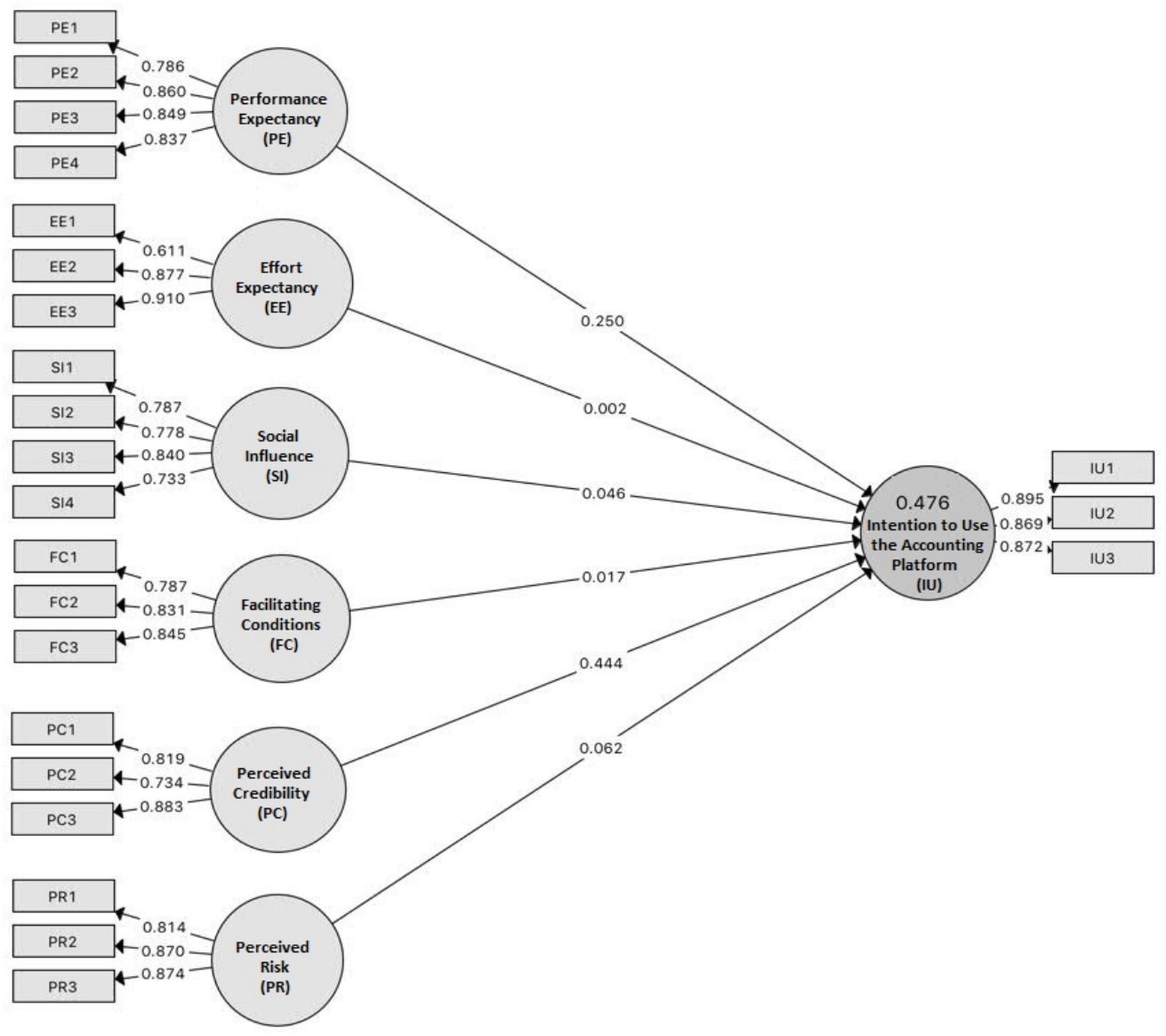

Figure 2. Partial least squares (PLS) algorithm results. 
The proposed model presents the indicators and paths connecting them to their own factors, the weights and loads being focused in the reflective and formative models that indicate the absolute and relative contributions of the indicator to the definition of its latent variable $[52,53]$.

Generally, the standardized path weights that connect the factors to the indicator variables can take values from 0 to 1 . Determining the square of the lowest load among the measurements: $0.733^{2}=0.53>0.50$ it is found that the measurement model is strong and reliable.

\subsection{The Measurement Model}

Because the model is reflective, composite reliability was preferred as an alternative to Cronbach's alpha, which may overestimate or underestimate the reliability of the scale in this case. Compared to Cronbach's alpha, composite reliability offers in model-based research PLS higher estimates of true reliability and records values from 0 to 1 , providing the opportunity for a perfect estimate.

In the case of exploratory research, the composite reliability must be equal to or greater than $0.6[52,54,55]$, equal to or greater than 0.7 [56], or equal to or greater than 0.8 [57]. This test was passed by all seven variables specific to the construct model included in our study (Table 2).

Table 2. Construct Reliability and Validity.

\begin{tabular}{cccc}
\hline & $\begin{array}{c}\text { Cronbach's } \\
\text { Alpha }\end{array}$ & $\begin{array}{c}\text { Composite } \\
\text { Reliability }\end{array}$ & $\begin{array}{c}\text { Average Variance } \\
\text { Extracted (AVE) }\end{array}$ \\
\hline Effort Expectancy (EE) & 0.733 & 0.848 & 0.657 \\
Facilitating Conditions (FC) & 0.759 & 0.861 & 0.674 \\
Intention to Use the Accounting Platform (IU) & 0.855 & 0.911 & 0.773 \\
Perceived Credibility (PC) & 0.751 & 0.854 & 0.663 \\
Perceived Risk (PR) & 0.813 & 0.889 & 0.728 \\
Performance Expectancy (PE) & 0.856 & 0.901 & 0.695 \\
Social Influence (SI) & 0.793 & 0.865 & 0.617 \\
\hline
\end{tabular}

Convergent validity is proved when latent factor indicators display values greater than or equal to 0.6 for an exploratory scale, 0.7 for an acceptable scale, and 0.8 for a good scale [52,55]. However, it should not be overlooked that Cronbach's alpha remains a conservative measure that may underestimate/overestimate reliability. The analyzed latent variables fall within these limits, fully registering levels above 0.7 . If the lowest value was obtained by the latent factor, effort expectancy (0.733), the highest level is reached by the variable performance expectancy $(0.856)$.

Average variance extracted (AVE) was used to test convergent and divergent validity, allowing the average community to be reflected for the seven latent variables included in the construct model. Following the recommendations of [58], the AVE values of all constructs should be greater than 0.5 and higher than cross-loading, justifying at least half of the variation of the respective factors [54,55]. The convergent validity test is tested; all latent factors of the construct model have values over 0.6. The lowest value is recorded by social influence $(0.617)$ while the highest is obtained by intention to use the accounting platform (0.773).

Evaluating the AVE values of the seven latent factors, it is observed that the discriminatory validity is also fulfilled. For example, for the intention to use the accounting platform variable, the square root of the AVE is 0.879 , which is greater than its correlation with any of the other latent variables-vertically $(0.879>0.643,0.485,0.557,0.247)$ and horizontally $(0.879>0.479,0.497)$.

As can be seen in Table 2 for the seven variables, the variation divided by its block of indicators remains larger than the variation it shares with any of the other latent variables. The square root of the AVE for the perceived risk factor $(0.853)$ is greater than the correlations below it $(0.853>0.603,0.264)$ or on its line $(0.853>0.558,0.485,0.693,0.411)$ (Table 3$)$. 
Table 3. Fornell-Larcker Criterion.

\begin{tabular}{|c|c|c|c|c|c|c|c|}
\hline Variables & 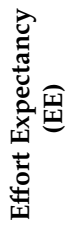 & 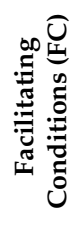 & 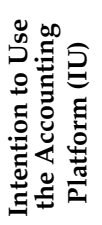 & 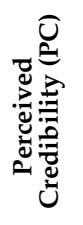 & 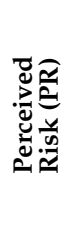 & 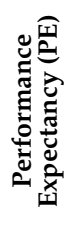 & 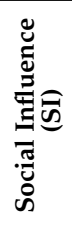 \\
\hline Effort Expectancy (EE) & 0.810 & & & & & & \\
\hline Facilitating Conditions (FC) & 0.525 & 0.821 & & & & & \\
\hline Intention to Use the Accounting Platform (IU) & 0.497 & 0.479 & 0.879 & & & & \\
\hline Perceived Credibility (PC) & 0.723 & 0.588 & 0.643 & 0.814 & & & \\
\hline Perceived Risk (PR) & 0.411 & 0.693 & 0.485 & 0.558 & 0.853 & & \\
\hline Performance Expectancy (PE) & 0.514 & 0.559 & 0.557 & 0.559 & 0.603 & 0.833 & \\
\hline Social Influence (SI) & 0.246 & 0.368 & 0.247 & 0.274 & 0.264 & 0.225 & 0.785 \\
\hline
\end{tabular}

An alternative to AVE as a method of assessing discriminate validity for reflective models is cross-loading [59]. In Table 3, all the indicator variables analyzed in our construct have a higher correlation with another latent variable than with its own latent variable. For the facilitating conditions (FC) factor, the loadings of articles on their own construction $0.845,0.831,0.787$ are higher than 0.7 while the cross-loadings are 0.394 (EE1), 0.415 (IU1), 0.292 (PC2), 0.370 (PE3), 0.496 (PR3), 0.260 (SI 3) or 0.509 (EE), 0.426 (IU), 0.574 (PC), 0.643 (PR), 0.523 (PE), 0.393 (SI) are between the levels of 0.2 and 0.5 . So, the facilitating conditions (FC) factor still has substantial cross-loadings with the indicators of the variables: perceived credibility (PC), performance expectancy (PE) and perceived risk (PR).

A similar situation is encountered in the case of the variable social influence (SI) where the loadings $0.840,0.778,733$, and 0.787 are higher than 0.7 and the cross-loadings 0.274 (PR2), 0.221 (PE4), 0.271 (PC1), 0.229 (IU3), 0.393 (FC3), and 0.235 (EE3) or 0.204 (PR), 0.177 (PE), 0.229 (PC), 0.226 (IU), 0.260 (FC), and 0.213 (EE) barely reach the 0.4 level (Table 4). The factor has the highest loading in relation to the facilitating conditions (FC) indicators. All indicator variables prove once again that the constructed model meets the condition of discriminated validity.

Table 4. Cross Loading.

\begin{tabular}{cccccccc}
\hline & $\begin{array}{c}\text { Effort } \\
\text { Expectancy } \\
\text { (EE) }\end{array}$ & $\begin{array}{c}\text { Facilitating } \\
\text { Conditions } \\
\text { (FC) }\end{array}$ & $\begin{array}{c}\text { Intention to Use } \\
\text { the Accounting } \\
\text { Platform (IU) }\end{array}$ & $\begin{array}{c}\text { Perceived } \\
\text { Credibility } \\
\text { (PC) }\end{array}$ & $\begin{array}{c}\text { Perceived } \\
\text { Risk (PR) }\end{array}$ & $\begin{array}{c}\text { Performance } \\
\text { Expectancy } \\
\text { (PE) }\end{array}$ & $\begin{array}{c}\text { Social } \\
\text { Influence } \\
\text { (SI) }\end{array}$ \\
\hline EE1 & 0.611 & 0.394 & 0.265 & 0.394 & 0.280 & 0.270 & 0.119 \\
EE2 & 0.877 & 0.393 & 0.393 & 0.591 & 0.279 & 0.395 & 0.222 \\
EE3 & 0.910 & 0.492 & 0.507 & 0.715 & 0.421 & 0.533 & 0.235 \\
FC1 & 0.363 & 0.787 & 0.344 & 0.426 & 0.426 & 0.362 & 0.223 \\
FC2 & 0.411 & 0.831 & 0.404 & 0.437 & 0.617 & 0.478 & 0.275 \\
FC3 & 0.509 & 0.845 & 0.426 & 0.574 & 0.643 & 0.523 & 0.393 \\
IU1 & 0.624 & 0.415 & 0.895 & 0.667 & 0.476 & 0.577 & 0.213 \\
IU2 & 0.323 & 0.419 & 0.869 & 0.488 & 0.374 & 0.427 & 0.212 \\
IU3 & 0.309 & 0.433 & 0.872 & 0.511 & 0.416 & 0.439 & 0.229 \\
PC1 & 0.403 & 0.589 & 0.531 & 0.819 & 0.608 & 0.478 & 0.271 \\
PC2 & 0.451 & 0.292 & 0.359 & 0.734 & 0.263 & 0.267 & 0.128 \\
PC3 & 0.843 & 0.508 & 0.628 & 0.883 & 0.449 & 0.558 & 0.244 \\
PE1 & 0.237 & 0.555 & 0.383 & 0.270 & 0.566 & 0.786 & 0.135 \\
PE2 & 0.292 & 0.508 & 0.399 & 0.365 & 0.568 & 0.860 & 0.214 \\
PE3 & 0.254 & 0.370 & 0.409 & 0.433 & 0.543 & 0.849 & 0.160 \\
PE4 & 0.761 & 0.448 & 0.597 & 0.682 & 0.390 & 0.837 & 0.221 \\
PR1 & 0.309 & 0.656 & 0.391 & 0.360 & 0.814 & 0.495 & 0.178 \\
PR2 & 0.386 & 0.633 & 0.417 & 0.484 & 0.870 & 0.538 & 0.274 \\
PR3 & 0.355 & 0.496 & 0.434 & 0.575 & 0.874 & 0.509 & 0.221 \\
SI1 & 0.168 & 0.325 & 0.193 & 0.190 & 0.237 & 0.239 & 0.787 \\
SI2 & 0.204 & 0.307 & 0.161 & 0.214 & 0.199 & 0.156 & 0.778 \\
SI3 & 0.213 & 0.260 & 0.226 & 0.229 & 0.204 & 0.177 & 0.840 \\
SI4 & 0.187 & 0.274 & 0.186 & 0.228 & 0.188 & 0.130 & 0.733 \\
\hline
\end{tabular}


The values in the Heterotrait-Monotrait Ratio (HTMT), although between a minimum of 0.264 for performance expectancy (PE) and a maximum of 0.761 for perceived credibility (PC) are below the reduction of 0.85 [60] once again demonstrating discriminant validity between the pairs of reflective constructs presented in the analyzed model.

\subsection{Structural Model}

Testing the research hypotheses and the evaluation of the structural model were based on the bootstrapping and blindfolding methods (with 5000 copies) which allowed the calculation of indicators such as: blocking significance for Path coefficients, average extracted variation (AVE), and blocked significance for R-square (the coefficient of determination).

Table 3 and Figure 2 contain the structural coefficients Path $(\beta)$ with the correspondence t-value that link the variables together. This being a standardized coefficient takes values from 0 to 1 . The higher the size of the structural coefficient, the stronger are the links between the variables [56]. For example, the loading for perceived credibility (PC) is 0.444 , indicating a positive but moderate correlation with intention to use the accounting platform (IU).

The beta paths for performance expectancy (0.250), perceived risk (0.062), social influence (0.046), facilitating conditions (0.017), and effort expectancy (0.002) are positive and significant, indicating that there are positive relationships between these variables and intention to use the accounting platform (IU) (Table 5).

Table 5. Results.

\begin{tabular}{|c|c|c|c|c|c|c|c|}
\hline Hypothesis & Correlation & I? & t-Value & $p$-Values & Decision & $R^{2}$ & Q2 \\
\hline H1 & $\begin{array}{l}\text { Performance Expectancy (PE)-Intention to } \\
\text { Use the Accounting Platform (IU) }\end{array}$ & 0.250 & 1.976 & 0.025 & Supported & & \\
\hline $\mathrm{H} 2$ & $\begin{array}{l}\text { Effort Expectancy (EE)-Intention to Use } \\
\text { the Accounting Platform (IU) }\end{array}$ & 0.002 & 0.033 & 0.973 & $\begin{array}{c}\text { Not } \\
\text { Supported }\end{array}$ & & \\
\hline $\mathrm{H} 3$ & $\begin{array}{l}\text { Social Influence (SI)-Intention to Use the } \\
\text { Accounting Platform (IU) }\end{array}$ & 0.046 & 1.984 & 0.023 & Supported & & \\
\hline $\mathrm{H} 4$ & $\begin{array}{l}\text { Facilitating Conditions (FC)-Intention to } \\
\text { Use the Accounting Platform (IU) }\end{array}$ & 0.017 & 0.186 & 0.852 & $\begin{array}{c}\text { Not } \\
\text { Supported }\end{array}$ & & \\
\hline H5 & $\begin{array}{l}\text { Perceived Credibility (PC)-Intention to } \\
\text { Use the Accounting Platform (IU) }\end{array}$ & 0.444 & 4.169 & 0.000 & Supported & 0.476 & 0.328 \\
\hline H6 & $\begin{array}{c}\text { Perceived Risk (PR)-Intention to Use the } \\
\text { Accounting Platform (IU) }\end{array}$ & 0.062 & 2.264 & 0.007 & Supported & & \\
\hline
\end{tabular}

In addition, R-square, which indicates the general measure of the effect size for the analyzed structural model, as in regression, represents $47.6 \%$ of the variation of the intention to use the accounting platform (IU) factor, demonstrating a moderate effect. No R-square was displayed for the remaining variables because they are exogenous latent factors [54].

The value of the Stone-Geisser coefficient $Q^{2}(0.328)$ is higher than 0 , therefore the analyzed structural model is predictive for the endogenous variable intention to use the accounting platform $\left(\mathrm{Q}^{2}>0\right.$ according to $\left.[54,61,62]\right)$. In our study, the value of the Goodness of Fit (GoF) indicator was 0.572 , higher than 0 , confirming once again that both the measurement and the structural model are predictive and fit well with the set of observations.

\section{Conclusions}

In this study we presented and validated a new construct model based on the successful UTAUT model. It captures the intention of using online accounting platforms by Romanian companies, offering on the one hand theoretical implications and on the other hand managerial implications.

This study is complementary to previous studies $[14,29,37,63]$ which have shown the role that the strategy of using accounting platforms available online has in the reframes of the business for 
sustainability. In the same line of thinking, these circumstances make companies benefit from the availability of financial big data.

\subsection{Theoretical Implications}

Four of the six hypotheses of the study are confirmed by the data obtained (H1, H3, H5, H6). The results of the analysis confirm the null hypothesis (H5) according to which perceived credibility (PC) has a positive, significant, and strong impact on the intention to use the accounting platform ( $\beta=0.444,4.169>1.96)$. Moreover, the construct model indicates a high correlation $(0.875)$ between ensuring the confidentiality of information on the use of services by the company (PC3) and the use of the online accounting platform that allows more time savings (PE4). Similarly, the null hypotheses $\mathrm{H} 1(\mathrm{t}$-value $=1.976), \mathrm{H} 3(\mathrm{t}$-value $=1.984)$ and H6 $(\mathrm{t}$-value $=2.264)$ were accepted. At the level of the researched population, performance expectancy $(\mathrm{PE})$ has a positive and significant impact on the variable intention to use the accounting platform online, which is certified by the acceptance of the null hypothesis $(\mathrm{H} 1)$ for $\beta=0.250$ and the $\mathrm{t}$-value distribution $=1.976$. A high correlation (0.718) at the model level exists between the importance of good control over the business (PE2) and the risk of quick access of third parties to company information (PR1).

The data in Table 3 confirm the $\mathrm{H}_{3}$ hypothesis according to which social influence (SI) has a positive, medium, but significant impact on the intention to use the accounting platform $(\beta=0.046$, $p<0.001)$. Between the assessments regarding the strategic involvement in community partnerships for solving some social problems (SI4) and the use of the accounting platform would allow for time savings (PE4), there is a lower correlation (0.146).

The last null hypothesis accepted was H6, suggesting that perceived risk (PR) exerts a positive and significant impact on the intention to use the accounting platform $(\beta=0.062, p<0.001)$. At the level of the constructed model, between the variables the organization of the accounting records using this platform is a risky choice PR3 and the accounting consultancy and the representation in case of control (PE3) a moderate correlation is observed. Exceptions are hypotheses $\mathrm{H} 2$ ( $\mathrm{t}$-value $=0.033$ ) and $\mathrm{H} 4$ ( $\mathrm{t}$-value $=0.017)$. Thus, effort expectancy $(\beta=0.002,0.033<1.96)$ and facilitating conditions $(\beta=0.017$, $0.186<1.96)$ positively but insignificantly affect the intention to use the accounting platform.

\subsection{Practical Implications}

The results of the current research show that the variables performance expectancy (PE), effort expectancy (EE), social influence (SI), facilitating conditions (FC), perceived credibility (PC), and perceived risk (PR) exert a positive influence on intention to use the accounting platform (IU).

At the level of the researched population, the average rating on performance expectancy (PE) was between 4.4-4.6 points on a scale from 1 to 5 . This indicates that the implementation of accounting platforms could offer users a multitude of advantages, such as: real-time reports, electronic archive containing all company documents and good business control (4446); consulting and accounting representation in case of control (4686); online invoicing and access to state-of-the-art technology through a simple, easy-to-use and $100 \%$ secure online accounting system (4601); save time because you no longer have to go with the documents to the accountant and no longer waste time in traffic (or with couriers) and improving the user experience of working with new platforms (4434).

Around level 4.5 is also the central trend of the effort expectancy (EE) data series. Respondents agree that using the online accounting platform would allow them to improve and expand their learning experience (4449); development of online communication skills (4524), and an easy level of interaction with the visual interface but also easier navigation (4519).

The average values obtained by the elements included in the social influence (SI) variable ranged between 3-4 points compared to the maximum 5 of the interval scale used in the construct model. Company managers agree that the use of accounting platforms creates new opportunities; among the most important of them we mention: knowing the behavior of employees, consumers, and suppliers (4030); promoting the achievements and traditions of the community (3963); understanding consumer 
behavior to substantiate future strategies and understanding the value of human nature for designing new products and services (4244); and last but not least, the strategic involvement in community partnerships for solving some social problems that ensure the increase of the company's reputation (4080).

The average perceived credibility (PC) rating was as high as the performance expectancy (PE) data series. Company managers are convinced that with the use of accounting platforms, procedures and techniques are developed to ensure the protection of users' business data with the help of antivirus/antimalware software systems (4676), to maintain business security by storing information in several servers (4202), and to ensure the confidentiality of all data, but especially of personal data (4474).

A favorable assessment from the respondents records all the elements of the facilitating conditions (FC) variable. Company managers encourage the use of accounting platforms recognizing that there are all the resources (4491) and the necessary knowledge (4469) and more can benefit from technical support to quickly solve any problems caused by their use (4626). The average perceived risk (PR) rating remains the highest $(>4.7)$. The appearance and use of accounting platforms is a real tool for business success, but also creates the premises for the emergence of new risks such as: the risk of rapid access of heads to information, documents or financial resources of the company (4744); the significant risk of disclosing business information for marketing purposes (4728) and the risks related to the organization and management of accounting with the help of the platform (4713).

Therefore, all the variables analyzed above can be taken into account by the management of the companies in the process of making the decision to use the digitized accounting services. In recent years, online accounting platforms are increasingly contributing to changing the image of the digital economy and producing more and more benefits to the contemporary digital society. They play an important role in creating "digital value," underpin future economic growth, and ensure the efficient functionality of the domestic digital market.

In the future, the authors intend to develop a new exploratory study on the net benefits of using online accounting platforms. Augmented reality could contribute to easier acceptance of online platforms by business management and transform the way they learn, communicate, and connect to markets, improving their financial and social results.

The main limitations of our study were related to information on the reference population from two different sources, relatively low response rate (33.41\%), and other studies that implemented the UTAUT model and used different endogenous variables.

Author Contributions: Conceptualization, G.C., I.O., and S.C.; methodology, M.C.T. and D.I.T.; validation, M.C.T. and S.C.; formal analysis, I.O. and D.D.; writing-original draft preparation, S.C. and M.C.T.; writing-review and editing, C.A.P. and A.N.S. All authors have read and agreed to the published version of the manuscript.

Funding: This research received no external funding.

Conflicts of Interest: The authors declare no conflicts of interest.

\section{Appendix A}

Table A1. Company sample.

\begin{tabular}{lcc}
\hline \multicolumn{1}{c}{ Characteristics } & Frequency & Percentage \\
\hline Indicate the size of your company. & & \\
\hline Less than 100 employees & 255 & 63.6 \\
Between 100 and 250 employees & 98 & 24.4 \\
More than 250 employees & 48 & 12.0 \\
Total & 401 & 100 \\
\hline
\end{tabular}


Table A1. Cont.

\begin{tabular}{lcc}
\hline \multicolumn{1}{c}{ Characteristics } & Frequency & Percentage \\
\hline In which industry does your company & primarily & operate? \\
\hline Farming/fishing/forestry & 26 & 6.5 \\
Chemical/pharmaceutical/medical & 35 & 8.7 \\
Commerce & 70 & 17.5 \\
Tourism & 43 & 10.7 \\
Energy/raw materials & 17 & 4.2 \\
Infrastructure/construction & 13 & 3.2 \\
Industry & 41 & 10.2 \\
IT/media & 52 & 13.0 \\
Consumer goods & 22 & 5.5 \\
Telecommunications & 6 & 1.5 \\
Logistics & 18 & 4.5 \\
Other industries & 58 & 14.5 \\
Total & 401 & 100 \\
\hline What is the legal organization of the business? & \\
\hline Joint stock company & 48 & 12.0 \\
Limited liability company & 137 & 34.2 \\
Authorized natural person & 60 & 15.0 \\
Individual/family enterprise & 44 & 11.0 \\
Non-governmental organization & 32 & 8.0 \\
Cooperative society & 21 & 5.2 \\
Other & 59 & 14.7 \\
Total & 401 & 100 \\
\hline Do you use accounting platform? & & \\
\hline No & 337 & 84.0 \\
Yes & 64 & 16.0 \\
Total & 401 & 100 \\
\hline
\end{tabular}

\section{References}

1. Davis, F.D.; Bagozzi, R.P.; Warsaw, P.R. User acceptance of computer technology: A comparison of two theoretical models. Manag. Sci. 1989, 35, 982-1003. [CrossRef]

2. Ferguson, C. The effect of computer micro on the works of the professional accountant. Account. J. 1997, 37, $41-67$.

3. Nasution, F. Information Technology Based Behavior Aspect. USU Digital Library 2006. Available online: http://library.usu.ac.id (accessed on 17 March 2020).

4. Shin, N.; Edington, B.H. An integrative framework for contextual factors affecting implementation of information technology. J. Inf. Technol. Theory Appl. 2007, 8, 21-38.

5. Davis, F.D. Perceived usefulness, perceived ease of use, and user acceptance of information technology. MIS Q. 1989, 13, 319-340. [CrossRef]

6. Venkatesh, V.; Morris, M.G.; Davis, G.B.; Davis, F.D. User acceptance of information technology: Toward a unified view. MIS Q. 2003, 27, 425-478. [CrossRef]

7. Fishbein, M.; Ajzen, I. Belief, Attitude, Intention and Behaviour: An Introduction to Theory and Research; Addison-Wesley: Boston, MA, USA, 1975.

8. Thompson, R.L.; Higgins, C.A.; Howell, J.M. Personal computing: Toward a conceptual model of utilization. MIS Q. 1991, 15, 124-143. [CrossRef]

9. Ajzen, I. Theory of Planned Behavior. Organ. Behav. Hum. Decis. Process. 1991, 50, 179-211. [CrossRef]

10. Davis, F.D.; Bagozzi, R.P.; Warshaw, P.R. Extrinsic and intrinsic motivation to use computers in the workplace. J. Appl. Soc. Psychol. 1992, 22, 1111-1132. [CrossRef]

11. Taylor, S.; Todd, P.A. Understanding the information technology usage: A test of competing models. Inf. Syst. Res. 1995, 6, 144-176. [CrossRef] 
12. Compeau, D.R.; Higgins, C.A.; Huff, S. Social cognitive theory and individual reactions to computing technology: A longitudinal study. MIS Q. 1999, 23, 145-158. [CrossRef]

13. Moore, G.C.; Benbasat, I. Development of an Instrument to Measure the Perceptions of Adopting an Information Technology Innovation. Inf. Syst. Res. 2001, 2, 173-239. [CrossRef]

14. CheMusa, Z.K.; Muhayiddin, M.N.; Yusoff, M.N.H.; Ismail, M.; Muhamad, M. Intention to Use Cloud Accounting System among SMEs in Malaysia: A Conceptual Framework of a Modified Unified Theory of Acceptance and Use of Technology (UTAUT) Model. Res. World Econ. 2019, 10, 74-78.

15. Islam, M.S.; Karia, N.; Khaleel, M.; Fauzi, F.B.A.; Soliman, M.S.M.; Khalid, J. Intention to adopt mobile banking in Bangladesh: An empirical study of emerging economy. Int. J. Bus. Inf. Syst. 2019, 31, 136-151. [CrossRef]

16. Chua, W.F. Interpretive sociology and management accounting research-A critical review. Account. Audit. Account. J. 1988, 1, 59-79. [CrossRef]

17. Adams, C.A.; Larrinaga-González, C. Engaging with organisations in pursuit of improved sustainability accounting and performance. Account. Audit. Account. J. 2007, 20, 333-355. [CrossRef]

18. Dobers, P.; Halme, M. Corporate social responsibility and developing countries. Corp. Soc. Responsib. Environ. Manag. 2009, 16, 237-249. [CrossRef]

19. Islam, M.A. Social and environmental accounting research: Major contributions and future directions for developing countries. J. Asia Pac. Cent. Environ. Account. 2010, 16, 27-43.

20. Watson, L. Corporate social responsibility research in accounting. J. Account. Lit. 2015, 34, 1-16.

21. Zyznarska-Dworczak, B. The development perspectives of sustainable management accounting in central and Eastern European countries. Sustainability 2018, 10, 1445. [CrossRef]

22. Fijałkowska, J.; Zyznarska-Dworczak, B.; Garsztka, P. Corporate social-environmental performance versus financial performance of banks in Central and Eastern European Countries. Sustainability 2018, 10, 772. [CrossRef]

23. Handayani, R. Analysis of Factors Affecting Interest in Information Systems Utilization and Use of Information Systems (Empirical Study of Manufacturing Companies on the Jakarta Stock Exchange). Master's Thesis, Accounting Science, Diponegoro University, Semarang, Indonesia, 2007.

24. Vankatesh, V.; Davis, F. A Theoretical Extension of the Technology Acceptance Model: Four Longitudinal Field Studies. Manag. Sci. 2000, 45, 186-204. [CrossRef]

25. Bhattacherjee, A. Understanding information systems continuance: An expectation confirmation model. MIS Q. 2001, 25, 351-370. [CrossRef]

26. Chen, J.L. The effects of education compatibility and technological expectancy on eLearning acceptance. Comput. Educ. 2011, 57, 1501-1511. [CrossRef]

27. Yuniman, A. Analysis of the Factors That Influence the Use and Use of Accounting Information Systems. Ph.D. Thesis, Faculty of Economics, University of Bengkulu, Bengkulu, Indonesia, 2012.

28. Rogers, E.; Shoemaker, F. Communication of Innovations; The Free Press: New York, NY, USA, 1971.

29. Zhou, T. Understanding mobile Internet continuance usage from the perspectives of UTAUT and flow. Inf. Dev. 2011, 27, 207-218. [CrossRef]

30. Bagozzi, R.P.; Lee, K.H. Multiple routes for social influence: The role of compliance, internalization, and social identity. Soc. Psychol. Q. 2002, 65, 226-247. [CrossRef]

31. Triandis, H. Value Attitude and Interpersonal Behavior, Nebraska Symposium on Motivation; Lincoln, N.E., Ed.; University of Nebraska Press: Lincoln, NE, USA, 1980.

32. Saha, S.K.; Zhuang, G.; Li, S. Will Consumers Pay More for Efficient Delivery? An Empirical Study of What Affects E-Customers' Satisfaction and Willingness to Pay on Online Shopping in Bangladesh. Sustainability 2020, 12, 1121. [CrossRef]

33. Lin, X.; Wu, R.; Lim, Y.T.; Han, J.; Chen, S.C. Understanding the Sustainable Usage Intention of Mobile Payment Technology in Korea: Cross-Countries Comparison of Chinese and Korean Users. Sustainability 2019, 11, 5532. [CrossRef]

34. Tran, V.; Zhao, S.; Diop, E.B.; Song, W. Travelers' Acceptance of Electric Carsharing Systems in Developing Countries: The Case of China. Sustainability 2019, 11, 5348. [CrossRef]

35. Lee, S.W.; Sung, H.J.; Jeon, H.M. Determinants of Continuous Intention on Food Delivery Apps: Extending UTAUT2 with Information Quality. Sustainability 2019, 11, 3141. [CrossRef] 
36. Palau-Saumell, R.; Forgas-Coll, S.; Sánchez-García, J.; Robres, E. User Acceptance of Mobile Apps for Restaurants: An Expanded and Extended UTAUT-2. Sustainability 2019, 11, 1210. [CrossRef]

37. Lee, J.; Kim, K.; Shin, H.; Hwang, J. Acceptance Factors of Appropriate Technology: Case of Water Purification Systems in Binh Dinh, Vietnam. Sustainability 2018, 10, 2255. [CrossRef]

38. Chuang, L.M.; Chen, P.C.; Chen, Y.Y. The Determinant Factors of Travelers' Choices for Pro-Environment Behavioral Intention-Integration Theory of Planned Behavior, Unified Theory of Acceptance, and Use of Technology 2 and Sustainability Values. Sustainability 2018, 10, 1869. [CrossRef]

39. Baganzi, R.; Lau, A.K.W. Examining Trust and Risk in Mobile Money Acceptance in Uganda. Sustainability 2017, 9, 2233. [CrossRef]

40. Gbongli, K.; Xu, Y.; Amedjonekou, K.M.; Kovács, L. Evaluation and Classification of Mobile Financial Services Sustainability Using Structural Equation Modeling and Multiple Criteria Decision-Making Methods. Sustainability 2020, 12, 1288. [CrossRef]

41. Zimmer, J.C.; Arsal, R.E.; Al-Marzouq, M.; Grover, Y. Investigating Online Information Disclosure: Effects of Information Relevance, Trust and Risk. Inf. Manag. 2010, 47, 115-123. [CrossRef]

42. Herrero, A.; San Martín, H. Effects of the risk sources and user involvement on e-commerce adoption: Application totourist services. J. Risk Res. 2012, 15, 841-855. [CrossRef]

43. Slade, E.L.; Dwivedi, Y.K.; Piercy, N.C.; Williams, M.D. Modeling consumers' adoption intentions of remotemobile payments in the United Kingdom: Extending UTAUT with innovativeness, risk, and trust. Psychol. Mark. 2015, 32, 860-873. [CrossRef]

44. Liébana-Cabanillas, F.; Mũnoz-Leiva, F.; Sánchez-Fernández, J. A global approach to the analysis of user behavior inmobile payment systems in the new electronic environment. Serv. Bus. 2018, 12, 25-64. [CrossRef]

45. Hair, J.F., Jr.; Hult, G.T.M.; Ringle, C.; Sarstedt, M. A Primer on Partial Least Squares Structural Equation Modeling (PLS-SEM); Sage Publications: Thousand Oaks, CA, USA, 2016.

46. Lorber, A.; Wangen, L.E.; Kowalski, B.R. A theoretical foundation for the PLS algorithm. J. Chemom. 1987, 1, 19-31. [CrossRef]

47. Mota, L.J.; Ramsden, A.E.; Liu, M.; Castle, J.D.; Holden, D.W. SCAMP3 is a component of the Salmonella-induced tubular network and reveals an interaction between bacterial effectors and post Golgi trafficking. Cell. Microbiol. 2009, 11, 1236-1253. [CrossRef]

48. Liu, P.; Long, W. Current matehmatical methods used in QSAR/QSPR studies. Int. J. Mol. Sci. 2009, 10, 1978-1998. [CrossRef] [PubMed]

49. Herrador-Alcaide, T.C.; Hernández-Solís, M.; Hontoria, J.F. Online Learning Tools in the Era of m-Learning: Utility and Attitudes in Accounting College Students. Sustainability 2020, 12, 5171. [CrossRef]

50. Badia, F.; Bracci, E.; Tallaki, M. Quality and Diffusion of Social and Sustainability Reporting in Italian Public Utility Companies. Sustainability 2020, 12, 4525. [CrossRef]

51. Joshi, A.; Kale, S.; Chandel, S.; Pal, D. Likert Scale: Explored and Explained. Br. J. Appl. Sci. Technol. 2015, 7, 396-403. [CrossRef]

52. Henseler, J.; Ringle, C.M.; Sarstedt, M. Using partial squares path modeling in international advertising research. Basic concepts and recent issues. In Handbook of Research in International Advertising; Okazaki, S., Ed.; Edward Elgar Publishing: Cheltenham, UK, 2012; pp. 252-276.

53. Henseler, J. Partial least squares path modeling. In Advanced Methods for Modeling Markets: International Series in Quantitative Marketing; Leeflang, P., Bijmolt, T., Pauwels, K., Eds.; Springer: Heidelberg, UK, 2017; pp. 361-381.

54. Chin, W.W. The partial least squares approach for structural equation modeling. In Modern Methods for Business Research; Macoulides, G.A., Ed.; Lawrence Erlbaum Associates: Mahwah, NJ, USA, 1998; pp. 295-336.

55. Höck, M.; Ringle, C.M. Strategic Networks in the Software Industry: An Empirical Analysis of the Value Continuum; IFSAM VIIIth World Congress: Berlin, Germany, 2006; Available online: http://www.ibl-unihh.de/IFSAM06. pdf (accessed on 22 March 2020).

56. Hair, J.F.J.; Black, W.C.; Babin, B.J.; Anderson, R.E.; Tatham, R.L. Multivariate Data Analysis; Prentice Hall: Upper Saddle River, NJ, USA, 2010.

57. Daskalakis, S.; Mantas, J. Evaluating the Impact of a Service-Oriented Framework for Healthcare Interoperability. Stud. Health Technol. Inform. 2008, 136, 285-290. [PubMed]

58. Fornell, C.; Larcker, D.F. Evaluating structural equation models with unobservable variables and measurement error. J. Mark. Res. 1981, 18, 39-50. [CrossRef] 
59. Clark, L.A.; Watson, D. Constructing validity: Basic issues in objective scale development. Psychol. Assess. 1995, 7, 309-319. [CrossRef]

60. Kline, R.B. Principles and Practice of Structural Equation Modeling; Guilford Press: New York, NY, USA, 2011.

61. Stone, M. Cross-validatory choice and assessment of statistical predictions. J. R. Stat. Soc. 1974, 36, 111-147. [CrossRef]

62. Geisser, S. A predictive approach to the random effects model. Biometrika 1974, 61, 101-107. [CrossRef]

63. Moore, W.B.; Poznanski, P.J. Sustainability Reporting: An Accountant's Perspective. J. Manag. Sustain. 2015, 5, 92-96. [CrossRef]

(C) 2020 by the authors. Licensee MDPI, Basel, Switzerland. This article is an open access article distributed under the terms and conditions of the Creative Commons Attribution (CC BY) license (http://creativecommons.org/licenses/by/4.0/). 